\title{
Glyphosate on digestive enzymes activity in piava (Leporinus obtusidens)
}

\author{
Glifosato sobre a atividade de enzimas digestivas em piavas (Leporinus obtusidens)
}

\author{
Joseânia Salbego ${ }^{I}$ Alexandra Pretto ${ }^{\text {II }}$ Vera Maria Machado da Silva ${ }^{I I}$ \\ Vania Lucia Loro ${ }^{\text {II }}$ Rafael Lazzari ${ }^{I I I}$ Carolina Rosa Gioda ${ }^{I V}$ Bernardo Baldisserotto $^{{ }^{*}}$
}

\section{ABSTRACT}

The effects of glyphosate, a nonselective herbicide (1.0 or $5.0 \mathrm{mg} \mathrm{L}^{-1}$ ) on digestive enzymes activity (stomach and intestine) were evaluated in juveniles of piava (Leporinus obtusidens) after 90 days of exposure. The activity of acid protease, trypsin, chymotrypsin and amylase increased with the increase of glyphosate concentration. These results indicate that glyphosate affects digestive enzyme activities in this species, and may be an indicator of poor nutrient availability when fish survive in herbicide-contaminated water.

Key words: fish, herbicide, acid protease, amylase, trypsin.

RESUMO

Os efeitos do glifosato, um herbicida não seletivo $\left(1,0\right.$ ou $\left.5,0 \mathrm{mg} \mathrm{L}^{-1}\right)$, sobre a atividade de enzimas digestivas (estômago e intestino) foram avaliadas em juvenis de piava (Leporinus obtusidens) após 90 dias de exposição. A atividade da protease ácida, tripsina, quimiotripsina e amilase aumentaram com a elevação da concentração de glifosato. Esses resultados indicam que o glifosato afeta a atividade de enzimas digestivas nesta espécie e pode ser indicador da reduzida disponibilidade de nutrientes, quando peixes sobrevivem em água contaminada com este herbicida.

Palavras-chave: peixe, herbicida, protease ácida, amilase, tripsina.

\section{INTRODUCTION}

Glyphosate, chemically known as isopropylamine salt of $\mathrm{N}$ - phosphonomethyl glycine, is a post-emergent herbicide widely used in several types of cultures (MODESTO \& MARTINEZ, 2010a,b) and in South America this herbicide is one of the most widely used following the introduction of glyphosate-resistant transgenic soybean (Glycine max) (SOSO et al., 2007). The most known worldwide commercial name for glyphosate is Roundup ${ }^{\mathrm{TM}}$ (GIESY et al., 2000).

The piava (Leporinus obtusidens) has great potential for fish culture due to its omnivorous feeding habit and ecological and economic importance to the Uruguay River Basin (REYNALTE-TATAJE \& ZANIBONI FILHO, 2010). Studies demonstrated that exposure of fish to glyphosate leads to oxidative stress, inhibited brain and muscle acetylcholinesterase activity, cause metabolic changes and impairs growth (MODESTO \& MARTINEZ, 2010a,b; SALBEGO et al., 2010; GLUSCZAK et al., 2011). Several studies indicate that growth rate in fish can be partially attributed to digestive capacity (BLIER et al., 2002; FILIPPOV et al., 2013). Therefore, the aim of this study was to verify the effect of chronic exposure to sublethal glyphosate concentrations on the activity of digestive enzymes of piava juveniles.

\section{MATERIAL AND METHODS}

Piava juveniles (mean \pm SEM; weight $=$ $8.0 \pm 0.5 \mathrm{~g}$ and length $=5.0 \pm 1.0 \mathrm{~cm})$ were obtained

\footnotetext{
'Departamento de Fisiologia e Farmacologia, Universidade Federal de Santa Maria (UFSM), Av. Roraima, 1000, 97105-900, Santa Maria RS, Brasil. E-mail: bbaldisserotto@hotmail.com.*Autor para correspondência.

IIDepartamento de Química, UFSM, Santa Maria, RS, Brasil.

IIIDepartamento de Zootecnia e Ciências Biológicas, Centro de Educação Superior Norte (CESNORS), UFSM, Palmeira das Missões, RS, Brasil.

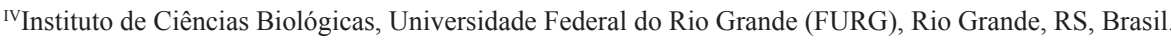
Received 10.21.13 Approved 03.07.14 Returned by the author 07.01.14 CR-2013-1399.R1
} 
from the Fish Culture Laboratory at the Universidade Federal de Santa Maria (UFSM). Fish were acclimated for ten days in 250L continuously aerated tanks with a static system and a natural photoperiod (14h light $10 \mathrm{~h}$ dark). After the acclimation period, fish were placed in $250 \mathrm{~L}$ continuously aerated tanks (30 fish per tank) and exposed for 90 days to 0 (control), 1.0 or $5.0 \mathrm{mg} \mathrm{L}^{-1}$ Roundup ${ }^{\mathrm{TM}}$ ( $48 \%$ acid equivalent of the isopropylamine salt of glyphosate, Monsanto Company, Saint Louis, MO, USA) diluted in water (two replicates). Roundup concentrations were chosen considering that the $0.36-2.16 \mathrm{mg} \mathrm{L}^{-1}$ range is used in agriculture and based on the estimated half-life of glyphosate (RODRIGUES \& ALMEIDA, 1998). The herbicide was reapplied in the tanks at 4-day intervals to maintain the expected concentration $(50 \%$ of the water was renewed at these moments) Glyphosate and its breakdown product aminomethylphosphonic acid (AMPA) were monitored according to HIDALGO et al. (2004) through eight days (Table 1). Throughout acclimation and experimental period, fish were fed once a day to satiety with commercial fish feed $(38 \%$ crude protein, Supra, Brazil). Feces and pellet residues were removed daily by suction. The water quality parameters were controlled daily: dissolved oxygen and temperature were measured with a YSI oxygen meter (Model Y5512). The $\mathrm{pH}$ was determined with a DMPH-2 pHmeter. Total ammonia nitrogen levels were measured with the salicylate method (VERDOUW et al., 1978). Water hardness was analyzed using the EDTA titrimetric method (EATON et al., 2005). The nitrite concentration and alkalinity were measured using the method of BOYD \& TUCKER (1992). The parameters remained within the appropriate levels for the species (Table 2) (REYNALTE-TATAJE \& ZANIBONI-FILHO, 2010).

Table 1 - Glyphosate concentration in the water of the experimental tanks through eight days.

\begin{tabular}{|c|c|c|}
\hline \multicolumn{3}{|c|}{---------------------Glyphosate $1 \mathrm{mg} \mathrm{L}^{-1}$} \\
\hline Day & Glyphosate $\left(\mathrm{mg} \mathrm{L}^{-1}\right)$ & AMPA $\left(\mathrm{mg} \mathrm{L}^{-1}\right)$ \\
\hline 1 & $1.01 \pm 0.001$ & $1.05 \pm 0.005$ \\
\hline 2 & $0.95 \pm 0.05$ & $1.02 \pm 0.06$ \\
\hline 4 & $0.95 \pm 0.004$ & $0.95 \pm 0.005$ \\
\hline 8 & $0.96 \pm 0.01$ & $0.97 \pm 0.05$ \\
\hline \multicolumn{3}{|c|}{-- Glyphosate $5 \mathrm{mg} \mathrm{L}^{-1}$} \\
\hline Day & Glyphosate (mg L $\left.{ }^{-1}\right)$ & AMPA $\left(\mathrm{mg} \mathrm{L}^{-1}\right)$ \\
\hline 1 & $5.1 \pm 0.002$ & $5.05 \pm 0.005$ \\
\hline 2 & $4.5 \pm 0.05$ & $4.4 \pm 0.06$ \\
\hline 4 & $4.5 \pm 0.005$ & $4.65 \pm 0.05$ \\
\hline 8 & $4.4 \pm 0.04$ & $4.55 \pm 0.06$ \\
\hline
\end{tabular}

$\mathrm{n}=3$ for each tank; values are expressed as mean \pm SEM.
Table 2 - Overall water quality parameters through 90 days of exposure of piava (Leporinus obtusidens) to different glyphosate levels (control, 1.0 or $5.0 \mathrm{mg} \mathrm{L}^{-1}$ ). Data are reported as the mean \pm SEM. There was no significant difference between treatments.

\begin{tabular}{ll}
\hline Parameters & \\
\hline Dissolved oxygen $\left(\mathrm{mg} \mathrm{L}^{-1}\right)$ & $7.2 \pm 0.2$ \\
Temperature $\left({ }^{\circ} \mathrm{C}\right)$ & $22 \pm 0.5$ \\
$\mathrm{pH}$ & $7.40 \pm 0.05$ \\
Total ammonia $\left(\mathrm{mg} \mathrm{L}^{-1}\right)$ & $0.05 \pm 0.001$ \\
Hardness $\left(\mathrm{mg} \mathrm{CaCO}_{3} \mathrm{~L}^{-1}\right)$ & $32.0 \pm 1.1$ \\
Nitrite $\left(\mathrm{mg} \mathrm{L}^{-1}\right)$ & $0.06 \pm 0.01$ \\
Alkalinity $\left(\mathrm{mg} \mathrm{CaCO}_{3} \mathrm{~L}^{-1}\right)$ & $39.0 \pm 3.2$ \\
\hline
\end{tabular}

At the end of the experimental period ( 90 days) eight fish from each replicate were sampled and killed by section of the spinal cord. Stomach and intestine were sampled, the content removed and the tissues placed in liquid nitrogen for posterior analysis of digestive enzymes activity. In the stomach amylase and acid protease activities were determined and in the intestine amylase, trypsin and chymotrypsin activities. Amylase activity was assayed in $0.2 \mathrm{M}$ phosphate-citrate buffer, $\mathrm{pH} 7.0,0.5 \% \mathrm{NaCl}$ with a starch concentration of $2.5 \%$. The reaction was stopped by adding $\mathrm{Ba}$ $(\mathrm{OH})_{2}, 0.3 \mathrm{~N}$ and $\mathrm{ZnSO}_{4} 5 \%$. The experimental protocol was modified according to BERNFELD (1955). The determination of starch hydrolysis was done following PARK \& JOHNSON (1949). The absorbance was recorded at $660 \mathrm{~nm}$. One unit of enzyme was defined as $1 \mathrm{mmol}$ of glucose released from starch per min per $\mathrm{mg}$ of protein. Total acid protease activity was measured using non-specific substrate (casein) according to HIDALGO et al. (1999). The assay was carried out using $0.2 \mathrm{M} \mathrm{KCl}$ buffer, $\mathrm{pH} 2.0$. The absorbance of the enzyme extract was recorded at $280 \mathrm{~nm}$. All samples were assayed in duplicate and readings corrected for blank solutions. Tyrosine was used as standard, and one unit of enzyme was defined as the amount of enzyme needed to catalyze the formation of $1.0 \mathrm{mg}$ of tyrosine per min per mg protein, according to HIDALGO et al. (1999). Trypsin activity (E.C.34.21.4) was assayed with toluenesulphonyl-L-arginine methyl ester hydrochloride (TAME). Crude extracts were incubated for $2 \mathrm{~min}\left(25^{\circ} \mathrm{C}\right)$ in $2 \mathrm{~mL}$ of Tris $/ \mathrm{CaCl}_{2}$ buffer, $\mathrm{pH} 8.1$. Chymotrypsin activity (E.C.34.21.1) was assayed with benzoyl tyrosine ethyl ester (BTEE). Crude extracts were incubated for $2 \mathrm{~min}$ in $2 \mathrm{~mL}$ of Tris $/ \mathrm{CaCl}_{2}$ buffer, $\mathrm{pH}$ 7.8. Both trypsin and chymotrypsin were assayed in duplicate and enzyme activities were recorded at 247 and 256nm, respectively, according to HUMMEL (1959). One unit of enzyme was defined as the amount of enzyme needed to hydrolyze $1 \mu \mathrm{g}$ of substrate (TAME 
or BTEE) per min per mg protein. Total protein content of crude extracts was measured following LOWRY et al. (1951), using bovine serum albumin as a standard. Data were assessed for normality using a ShapiroWilk test and submitted to one-way ANOVA followed by Duncan test $(P<0.05)$, and values expressed as mean \pm standard error $(n=8)$. All statistics were carried out using $\operatorname{SAS}^{\circledR}$ (1997) software.

\section{RESULTS AND DISCUSSION}

Fish survival was not affected by glyphosate levels, being $100 \%$ in all treatments. Glyphosate in water of experimental tanks was monitored for eight days (Table 1) and glyphosate concentration in the water was adjusted according to treatments.

Digestive enzymes activities in all portions of the gastrointestinal tract increased significantly in piavas exposed to both glyphosate concentrations except amylase in the stomach of those exposed to $1.0 \mathrm{mg} \mathrm{L}^{-1}$ (Figure 1). The higher amylase activity in the intestine than in the stomach of piavas (Figure 1A and 1B) is expected for typically omnivorous species (NAMULAWA et al., 2013). Long-term exposure (90 days) to glyphosate 1.0 or $5.0 \mathrm{mg} \mathrm{L}^{-1}$ did not affect feed intake but reduced growth and caused hematological and metabolic disruption in piavas (SALBEGO et al., 2010).

The growth and food efficiency in fish depends on their physiological and biochemical

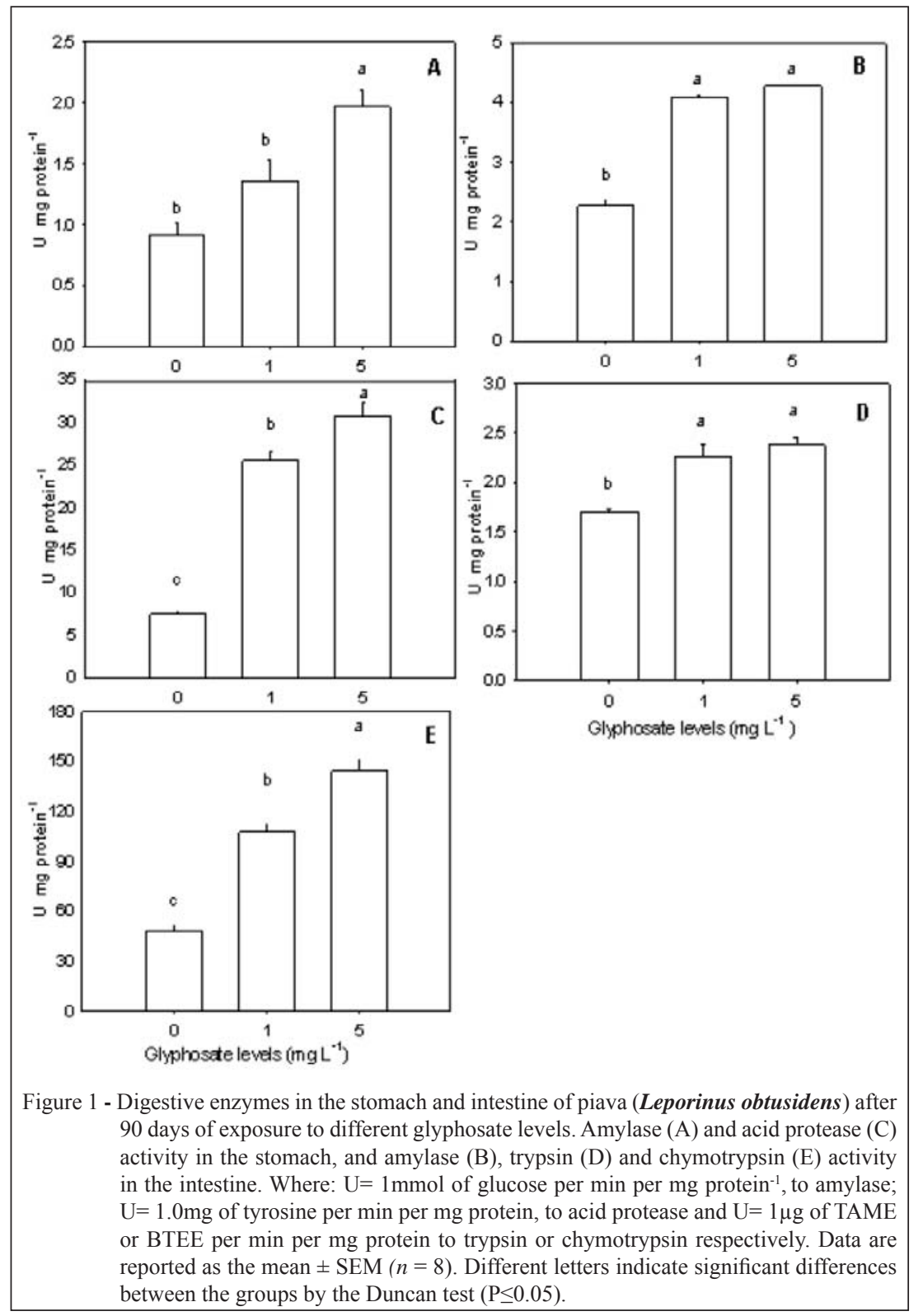

Ciência Rural, v.44, n.9, set, 2014. 
capacities to digest and transform ingested nutrients (SWEILUM, 2006; FURNÉ et al., 2008; LAZZARI et al., 2010). BLIER et al. (2002) suggests that growth can be determined by some factors: the activity of digestive enzymes, the availability of oxygen for metabolism and the protein synthesis. The herbicides and pesticides in general can affect oxygen availability for the tissues (ORUÇ \& UNER, 1999; GIMENO et al., 1995; BEGUM, 2004).

Metabolic alterations can also intervene in the growth process. SALBEGO et al. (2010) attributed the growth reduction in piavas exposed to glyphosate to several factors: lower exploitation of the available nutrients, reduction of the oxygen in tissues confirmed by fermentative response in the liver and muscle. These alterations suggest that for the maintenance of the fish in glyphosate-contaminated water, a great demand of energy is required. The increase in the activity of digestive enzymes may be an attempt of the organism to increase the exploitation of the food, compensating other possible losses caused by the poisoning.

The digestive enzymes activity reflects in the capacity of exploitation of the food by the fish and that the induction of determined enzymes is directly related to the type of diet (TORRISSEN \& SHEARER, 1992). The obtained results allow concluding that low growth observed in glyphosate-exposed piavas by SALBEGO et al. (2010) may be related (at least partially) to the change in digestive enzymes activity.

\section{CONCLUSION}

In conclusion, present study demonstrated that long-term exposure to Roundup ${ }^{\circledR}$ increased digestive enzymes activity in piavas probably as a compensatory mechanism to obtain nutrients, indicating Roundup ${ }^{\circledR}$ toxicity. The piava and digestive enzymes activity in this fish may be useful as biondicator and biomarkers of long-term exposure to commercial formulations containing glyphosate.

\section{ACKNOWLEDGMENTS}

This study was supported by Fundação de Amparo à Pesquisa no Rio Grande do Sul (FAPERGS), process number 040546.0. B. Baldisserotto and V. L. Loro received research fellowships from the Conselho Nacional de Desenvolvimento Científico e Tecnológico (CNPq) and J. Salbego fellowship from Coordenação de Aperfeiçoamento de Pessoal de Nível Superior (CAPES).

\section{ETHICAL STATEMENT}

We declare to whom correspond that we assume any responsibility about any process performed during the development of the research entitled "Effects of glyphosate on digestive enzyme activity in piava (Leporinus obtusidens)". Likewise we are available to answer any questions that may be needed.

\section{REFERENCES}

BEGUM, G. Carbofuran insecticide induced biochemical alterations in liver and muscle tissues of the fish Clarias batrachus (linn) and recovery response. Aquatic Toxicology, v.66, p.83-92, 2004. Available from: <http://ac.els-cdn.com/ S0166445X03001930/1-s2.0-S0166445X03001930-main.pdf? $\mathrm{tid}=8 \mathrm{~d} 7 \mathrm{a} 1 \mathrm{ce} 2-7 \mathrm{c} 6 \mathrm{f}-11 \mathrm{e} 3-8613-00000 \mathrm{aab} 0 \mathrm{f} 26 \& \mathrm{acdnat}=1389630$ 610 967be2d5c4a5b3225d7ec406bee0acf6>. Accessed: Jan. 13, 2014. doi:10.1016/j.aquatox.2003.08.002.

BERNFELD, P. Amylases a and b: colorimetric assay methods. In: COLOWICK, S.P.; KAPLAN, N.O. (Eds.). Methods in enzymology. New York: Academic, 1955. p.149-158.

BLIER, P.U.; LEMIEUX, H.; DEVLIN, R.H. Is the growth of fish set by digestive enzymes or metabolic capacity of the tissues? Insight from transgenic coho salmon. Aquaculture, v.209, p.379-384, 2002. Available from: <http://ac.els-cdn.com/S0044848601008079/1s2.0-S0044848601008079-main.pdf? tid $=\mathrm{d} 3 \mathrm{fe} 7 \mathrm{~b} 36-2157-11 \mathrm{e} 3-$ a904-00000aab0f6b\&acdnat $=1379614865[2 b 2383 \mathrm{fbfd} 9 \mathrm{c} 9 \mathrm{cfa} 4 \mathrm{ce}>$ bab88d5c09b83. Accessed: Sept. 19, 2013.

BOYD, C.E.; TUCKER, C.S. Water quality and pond soil analyses for aquaculture. Alabama: Alabama Agricultural Experiment Station, Auburn University, 1992. 183p.

EATON, A.D. et al. Standard methods for the examination of water and wastewater. 21.ed. Springfield: American Public Health Association, 2005. 1368p.

FILIPPOV, A.A. et al. Effects of organic pollutants on fish digestive enzymes: a review. Inland Water Biology, v.6, p.155160, 2013. Available from: <http://link.springer.com/article/10.11 34\%2FS199508291302003X\#page-1>. Accessed: Sept. 19, 2013. doi:10.1134/S199508291302003X

FURNÉ, M. et al. Effect of starvation and refeeding on digestive enzyme activities in sturgeon (Acipenser naccarii) and trout (Oncorhynchus mykiss). Comparative Biochemistry and Physiology (A), v.149, p.420-425, 2008. Available from: <www. ncbi.nlm.nih.gov/pubmed/18328757>. Accessed: Oct. 10, 2013. doi:10.1016/j.cbpa.2008.02.002.

GIESY, J.P. et al. Ecotoxicological risk assessment for roundup herbicide. Environmental Contamination and Toxicology, v.167, p.35-120, 2000. Available from: <http://link.springer.com/chapter/10.1007/9781-4612-1156-3_2\#page-1>. Accessed: Sept. 19, 2013.

GIMENO, L. et al. Pesticide effects on eel metabolism. Ecotoxicology and Environmental Safety, v.31, p.153-157, 1995. Available from: <http://ac.els-cdn.com/S0147651385710561/1s2.0-S0147651385710561-main.pdf? tid=2871 ae98 $7 \mathrm{c} 72-11 \mathrm{e} 3-8100-00000 \mathrm{aab} 0 \mathrm{f} 6 \mathrm{~b} \& \mathrm{acdnat}=1389631729$ bc11dc4e2456338ba7f017003e2c9ae6>. Accessed: Jan. 13, 2014.

GLUSCZAK, L. et al. Acute exposure to glyphosate herbicide affects oxidative parameters in piava (Leporinus obtusidens). Archives of Environmental Contamination and Toxicology, v.61, p.624-630, 2011. Available from: $<$ http://download.springer.com/static/pdf/623/ar $\mathrm{t} \% 253 \mathrm{~A} 10.1007 \% 252 \mathrm{Fs} 00244-011-9652-4$.pdf?auth66=1379788806 e97ec965a8c5f16d750110451aa26b d6\&ext=.pdf $>$. Accessed: Sept. 19, 2013. doi: 10.10 07/s00244-011-9652-4. 
HIDALGO, M.C. et al. Comparative study of digestive enzymes in fish with different nutritional habits. Proteolytic and amylase activities. Aquaculture, v.170, p.267-283, 1999. Available from: $<$ http://ac.els-cdn. com/S004484869800413X/1-s2.0-S004484869800413X-main.pdf? tid $=$ cc3f085e-7c72-11e3-8614-00000aab0f26\&acdnat=1389632004_81 ce406d86b8e1217d669d5a154 5a634>. Accessed: Jan. 13, 2014.

HIDALGO, C. et al. Improved coupled-columm liquid chromatographic method for the determination of glyphosate and aminomethylphosphonic acid residues in environmental waters. Journal of Chromatography A, v.1035, p.153-157, 2004 Available from: <http://ac.els-cdn.com/S0021967304002511/1s2.0-S0021967304002511-main.pdf?_tid=3a45de2c-7c73-11e3897f-00000aab0f02\&acdnat $=1389632189$ d27f0ee44a25a9f2 216b14e9138496d5>. Accessed: Jan. 13, 2014 . doi:10.1016/j. chroma.2004.02.044.

HUMMEL, B.C.W. A modified Spectrophotometric determination of chymotrypsin, trypsin and thrombin. Canadian Journal of Biochemistry and Physiology, v.37, p.1393-1399, 1959.

LAZZARI, R. et al. Protein sources and digestive enzyme activities in jundia (Rhamdia quelen). Scientia Agricola, v.67, n.3, p.259-266, 2010. Available from: <http://www.scielo.br/pdf/ sa/v67n 3/a02v67n3.pdf>. Accessed: Jan. 13, 2014.

LOWRY, O.H. et al. Protein measurement with Folin-phenol reagent. Journal of Biological Chemistry, v.193, p.265-275, 1951. Available from: <http://www.jbc.org/content/193/1/265. full.pdf + html $>$. Accessed: Jan. 13, 2014.

MODESTO, K.A.; MARTINEZ, C.B.R. Roundup causes oxidative stress in liver and inhibits acetylcholinesterase in muscle and brain of the fish Prochilodus lineatus. Chemosphere, v.78, p.294-299, 2010a. Available from: <http://ac.els-cdn.com/ S0045653509012739/1-s2.0-S0045653509012739-main.pdf? tid=b29040a4-215e-11e3-a2b1-00000aab0f01\&acdnat=13796178 15_0e4079ed67307957fcebd3601499bdea $>$. Accessed: Sept. 19, 2013. doi:10.1016/j.chemosphere.2009.1 0.047.

MODESTO, K.A.; MARTINEZ, C.B.R. Effects of Roundup Transorb on fish: hematology, antioxidant defenses and acetylcholinesterase activity. Chemosphere, v.81, p.781787, 2010b. Available from: <http://ac.els-cdn.com/ S0045653510007721/1-s2.0-S0045653510007721-main.pdf? tid $=9 \mathrm{bc} 8$ ee $10-215 \mathrm{f}-11$ e3-9482-00000aab0f01\&acdnat $=1379618 \overline{2}$ 07_1e4c37eedadc820833a8d a37e02fbb80>. Accessed: Sept. 19, 2013. doi:10.1016/j.chemosphere.2010.07.005.

NAMULAWA, V.T. et al. Enzyme activity in the Nile perch gut: implications to Nile perch culture. International Journal of Fisheries and Aquaculture, v.5, p.221-228, 2013. Available from: <http:// www.academicjournals.org/ijfa/PDF/pdf2013/Sep/Namulawa\%20 et\%20al.pdf>. Accessed: Sept. 19, 2013. doi:10.5897/IJFA13.0349.

ORUÇ, E.Ö.; ÜNER, N. Effects of 2,4-Diamin on some parameters of protein and carbohydrate metabolisms in the serum, muscle and liver of Cyprinus carpio. Environmental Pollution, v.105, p.267-272, 1999. Available from: <http://ac.els-cdn.com/ S0269749198002061/1-s2.0-S0269749198002061-main.pdf? tid=961 db8b6-7c76-11e3-9f39-00000aab0f02\&acdnat=138963363 1_42fadddec358151947f1d81efe2ff82c>. Accessed: Jan. 13, 2014.

PARK, J.T.; JOHNSON, M.J. A submicro determination of glucose. Journal of Biological Chemistry, v. 181, p.149-151, 1949.

REYNALTE-TATAJE, D.; ZANIBONI-FILHO,E. Cultivo de piapara, piauçu, piava e piau - gênero Leporinus. In: BALDISSEROTTO, B.; GOMES, L.C. (Eds.). Espécies nativas para piscicultura no Brasil. 2.ed. Santa Maria: UFSM, 2010. p.73-99.

RODRIGUES, B.N.; ALMEIDA, F.S. Guia de herbicidas. 4.ed. Londrina: Agris, 1998. 648p.

SALBEGO, J. et al. Herbicide formulation with glyphosate affects growth, acetylcholinesterase activity, and metabolic and hematological parameters in piava (Leporinus obtusidens). Archives of Environmental Contamination and Toxicology, v.58, p.740-745, 2010. Available from: <http://link.springer.com/ article/10.1007/s00244-009-9464-y\#page-1>. Accessed: Sept. 19, 2013. doi: 10.1007/s00244-009-9464-y.

SOSO, A.B. et al. Chronic exposure to sub-lethal concentration of a glyphosate-based herbicide alters hormone profiles and affects reproduction of female jundiá (Rhamdia quelen). Environmental Toxicology and Pharmacology, v.23, p.308-313, 2007. Available from: <http://ac.els-cdn.com/S1382668906001578/1-s2.0-S1382 668906001578-main.pdf?_tid=30dd126c-2163-11e3-863300000 aacb362\&acdnat $=1379619745 \_7 \mathrm{dab} 11677 \mathrm{fdd} 2551 \mathrm{~d} 02$ 5a62ed875c740>. Accessed: Sept. 19, 2013. doi: 10.1016/j. etap.2006.11.008.

SWEILUM, M.A. Effect of sublethal toxicity of some pesticides on growth parameters, haematological properties and total production of Nile tilapia (Oreochromis niloticus L.) and water quality of ponds. Aquaculture Research, v.37, p.10791089, 2006. Available from: <http://onlinelibrary.wiley.com/ doi/10.1111/j.1365-2109.2006.01531.x/pdf>. Accessed: Sept. 19, 2013. doi: 10.1111/j.1365-2109.2006.01531.x.

TORRISSEM, K.R.; SHEARER, K.D. Protein digestion, growth and food conversion in Atlantic salmon and Arctic charr with different trypsine-like isozyme patterns. Journal of Fish Biology, v.41, p.409-415, 1992.

VERDOUW, H. et al. Ammonia determination based on indophenols formation with sodium salicylate. Water Research, v.12, p.399-402, 1978. Available from: $<$ http://ac.els-cdn.com/0043135478901070/1s 2.0-0043135478901070-main.pdf?_tid=7c4fcfeed2cd-11e2-bf0e-00000a acb361\&acdnat $=1370979257$. e9c2f67a83c160480a29a351af793466>. Accessed: Jan. 13, 2014. doi:10.1016/0043-1354(78) 90107-0. 